\title{
Online Parenting guidelines to prevent adolescent depression and anxiety: Evaluating user characteristics and usefulness
}

\author{
Marie B H Yap ${ }^{1,2 \S}$, Peter D Martin ${ }^{1}$, Anthony F Jorm ${ }^{2}$
}

${ }^{1}$ School of Psychological Sciences, Monash Institute of Cognitive and Clinical

Neurosciences, Monash University, 18 Innovation Walk, Clayton, Victoria 3800, Australia

${ }^{2}$ Melbourne School of Population and Global Health, University of Melbourne, 207 Bouverie

Street, Carlton 3053, Australia

${ }^{\S}$ Corresponding author: Dr Marie Yap

Postal address: School of Psychological Sciences, Monash University, 18 Innovation Walk,

Clayton, Victoria 3800, Australia

Email address: marie.yap@monash.edu

Tel: +61399050723

\section{Acknowledgements}

The development of the Parenting guidelines was completed in partnership with beyondblue: the national depression and anxiety initiative, who also supported the launch and promotion of the guidelines. The current study was funded by the National Health and Medical Research Council (NHMRC). Author Yap received salary support from an NHMRC Career Development Fellowship (APP1061744). Author Jorm received salary support from an NHMRC Senior Principal Research Fellowship (APP1059785). The funding sources did not have any role in the conduct or publication of this study. 


\section{Abstract}

Aim

The aims of this study were to evaluate user characteristics and the perceived usefulness of a set of online parenting guidelines to prevent adolescent depression and anxiety.

\section{Methods}

Upon downloading the online guidelines, users were invited to complete a brief demographic survey assessing user characteristics (Survey 1). Consenting respondents were emailed an evaluation survey one month later, which assessed perceived usefulness of the guidelines (Survey 2).

\section{Results}

Over 22 months, 2631 users completed Survey 1 and 233 completed Survey 2. Most users endorsed the usefulness of the guidelines, and most parent users reported at least a little improvement on their parenting. Users were favourable towards a web-based parenting program as one way to improve the guidelines.

\section{Conclusions}

Findings suggest that the online guidelines may be a useful and sustainable universal prevention strategy for parents of adolescents.

\section{Key words}

Adolescent; Internet; Parents; Preventive Psychiatry; Public Health 


\section{Introduction}

As the incidence of depression and anxiety disorders peaks during adolescence (Kessler et al., 2007; Thapar, Collishaw, Pine, \& Thapar, 2012), this is an opportune time to target preventive efforts. The family environment, or parents/caregivers in particular, is a strategic but hitherto overlooked setting for targeting preventive interventions for youth depression and anxiety disorders (Yap et al., 2016). Burgeoning evidence has demonstrated that many key risk factors for these disorders involve families, such as marital conflict (Yap, Pilkington, Ryan, \& Jorm, 2014). Other factors can be detected early by parents, such as behaviourally inhibited temperament (Beesdo, Knappe, \& Pine, 2009), or are directly socialised or modelled by parents, such as parental responses to child emotions (Schwartz et al., 2012). Moreover, a recent systematic review and meta-analysis found that preventive interventions primarily targeting parents have beneficial effects on the child's internalizing outcomes lasting up to 11 years post-intervention (Yap et al., 2016).

However, despite this robust evidence base, parents' knowledge about what they can do to reduce their adolescent's risk of depression is less than optimal (Yap \& Jorm, 2012), highlighting a need to equip parents through more effective translation of evidence into preventive resources for parents. As an initial step towards addressing this need, Yap and colleagues developed a set of parenting guidelines through: (1) a systematic review and metaanalysis of parental factors associated with adolescent depression and/or anxiety (Yap, Pilkington, Ryan, \& Jorm, 2014); and (2) a Delphi study of international expert consensus about actionable strategies parents can use to reduce their child's risk of depression and anxiety (Yap, Pilkington, Ryan, Kelly, \& Jorm, 2014). The guidelines, titled 'How to prevent depression and anxiety in your teenager: Strategies for parents' (henceforth 'the guidelines'; Parenting Strategies Program, 2013), were made available for free download from the 
Parenting Strategies website, www.parentingstrategies.net/depression in August 2013 (see Table 1 for examples of guidelines recommendations and their links to the evidence base). Given its rapidly increasing reach, the Internet offers a valuable medium for disseminating evidence-based guidance for preventive action. Mental health is one of the most common topics searched by internet users (Powell \& Clarke, 2006), and in a recent national survey, $33 \%$ of parents/caregivers of children with mental disorders had sought mental health information online (Lawrence et al., 2015). However, there is a dearth of evidence regarding the impact that such information has on actual health behaviours (Reavley \& Jorm, 2010). More recently, studies have evaluated users' reported impact from accessing mental-health related guidelines online (Berk et al., 2013; Hart, Jorm, Paxton, \& Cvetkovski, 2012; Melioli, Rispal, Hart, Chabrol, \& Rodgers, 2016; Sim, Jones, Jorm, \& Yap, 2017). Albeit preliminary, these studies suggest that accessing evidence-based mental health guidelines is acceptable and can positively influence health-related behaviours.

Despite no ongoing active promotion of the guidelines, the website attracted large numbers of visits, with 26,977 recorded between 9 August 2013 and 31 May 2015 (660 days), which averages 41 visits per day. Nonetheless, it remains unclear whether accessing the guidelines yields any benefits. Hence, this study had three aims: (1) to describe the characteristics of online users who downloaded the guidelines; (2) to evaluate the perceived usefulness of the guidelines and their perceived impact on parenting behaviours; and (3) to explore users' suggestions for improving the guidelines.

\section{Methods}

\section{Participants and procedure}

The guidelines were promoted primarily through beyondblue: the national depression and anxiety initiative. Visitors to the www.parentingstrategies.net/depression website were 
invited to complete two online surveys, one-month apart, which assessed user characteristics (Survey 1) and the perceived impact of the guidelines (Survey 2). Upon attempting to download the guidelines, users were presented an invitation on a pop-up window to participate in Survey 1. Respondents were asked to provide an email address if they were willing to be contacted for the second survey.

There was no exclusion criteria for Survey 1 participation. However, as the guidelines were developed for parents of adolescents and require a moderate level of competency in the English language to understand and implement, Survey 2 excluded users if they were aged 16 or below or did not consider themselves fluent in English. In total, 2631 users ( $M$ age $=45.51$, $\mathrm{SD}=8.31)$ completed Survey 1 , and $233(M$ age=47.06, SD=7.46) completed Survey 2 (see Figure 1 for flow of participants).

The study was approved by the University of Melbourne Human Research Ethics Committee.

\section{Measures}

The two surveys were administered online through www.parentingstrategies.net/depression. Survey 1 contained 9 questions assessing demographic characteristics and reasons for downloading the guidelines (see Table 1 for questions). Survey 2 had two versions: one for parents/caregivers (10 questions; see Tables 2-5) and one for other eligible participants (e.g. professionals; 9 questions; see Tables 2, 3, and 5). Both versions had similar questions except for Question 7 in the Parent version, which asked about changes in parenting (see below).

\section{Results}

Most survey completers were female, parents/caregivers, and Australian residents. Table 1 shows Survey 1 responses, and comparisons of participants who completed both surveys with Survey 1 completers (which revealed no notable differences). 


\section{Perceived usefulness of the guidelines}

As shown in Table 2, most users endorsed the guidelines' usefulness. Few differences were observed between groups, although more parents than non-parents were 'moderate' in their positive responses (i.e. 'Mostly'/'useful' rather than 'Yes'/‘very useful').

Qualitative content analysis of responses to "Would you like to comment on why you found the guidelines useful or not useful?" is summarised in Table 3.

\section{Impact of the guidelines}

Parents/Caregivers reported the extent to which they had tried improving in 13 parenting domains since reading the guidelines (see Table 4). The guidelines seemed to motivate at least a little change for many parents, although to differing degrees for different parenting domains.

\section{Ways to improve the guidelines}

As shown in Table 5, most Survey 2 completers endorsed the usefulness of three proposed ways of presenting the guidelines, particularly interactive web-based parenting programs. When asked about ways to improve the guidelines, participants suggested different ways of formatting and delivering the guidelines; or additional support for their implementation (see Table 6).Discussion

The findings indicate that a set of evidence-based parenting guidelines made available online for free download attracted substantial interest from users internationally despite minimal 
ongoing promotion. Most users were parents/caregivers and female, consistent with past research related to parenting/family processes and child health (Yap \& Jorm, 2015). Most users downloaded the guidelines because they were concerned about children in their care, and/or wanted to know how they can prevent internalising problems in their children. This is in line with health behaviour theories such as the Health Belief Model, which posits that increased perceived susceptibility increases the likelihood of taking health-related actions (Rosenstock, 1974). Additionally, most of the users who completed the evaluation survey reported reading most or all of the guidelines, and finding them to be of value: saving/keeping them, learning 'a fair bit' to 'a great deal' from them, finding them relevant and useful, and being likely or very likely to use them in the future.

Parent users also reported that they tried to make changes to their parenting as a result of reading the guidelines. In particular, of the 13 parenting domains assessed, $>75-80 \%$ of parents reported a little to a lot of change in 4 domains (Helping your child to deal with problems, Helping your child to deal with anxiety, Minimising conflict with your child, Encouraging supportive relationships), and 70-75\% in 5 other domains (Encouraging good health habits, Supporting your child's increasing autonomy, Avoiding criticising your child, Establishing family rules and consequences, Improving your relationship with your child). While these findings reflect parents' perceptions of their own behaviours (and need to improve), rather than actual measurement of change in behaviours, they suggest that the guidelines yielded significant perceived impact on multiple parenting factors that are known to influence adolescents' risk of depression and anxiety (Yap, Pilkington, Ryan, \& Jorm, 2014). These findings are promising given that the guidelines can be disseminated widely at minimal additional cost, making it a sustainable universal prevention strategy. For example, the guidelines can be incorporated as the lowest-intensity option within a multi-level 
approach to support parents in caring for their child's mental health (Yap et al., under review).

Users' feedback about ways to improve the guidelines highlighted a preference for interactive formats which provide additional support to help parents implement the guidelines, including strategies to overcome potential barriers to implementation. In particular, an interactive webbased program was most highly favoured, indicating the promise of applying persuasive technology principles (Oinas-Kukkonen \& Harjumaa, 2009) to the design of a parenting program based on the guidelines, as was done for the Parenting Strategies: Preventing Adolescent Alcohol Misuse program (www.parentingstrategies.net; Yap et al., 2011).

Limitations of this study include the self-selection of participants, sole reliance on self-report of perceptions rather than actual behaviour, and high attrition between Surveys 1 and 2. The attrition rate in this study is comparable to two other recent guidelines evaluation studies (Melioli et al., 2016; Sim et al., 2017), and high attrition is more the norm than an exception in e-health research, especially with self-help programs (Eysenbach, 2005). Indeed, Eysenbach (2005) suggested various innovative techniques that can be used to analyse data from e-health trials with high attrition rates. Although our analyses revealed few differences between completers of only Survey 1 and completers of both surveys, it is possible that the two groups may differ in other ways that impact the outcomes of this study (e.g. users with less favourable perceptions may have dropped out).

In conclusion, the uptake and favourable perceptions of the guidelines suggest their potential as a low-cost universal prevention strategy for parents of adolescents. 


\section{References}

Beesdo, K., Knappe, S., \& Pine, D. S. (2009). Anxiety and Anxiety Disorders in Children and Adolescents: Developmental Issues and Implications for DSM-V. The Psychiatric clinics of North America, 32(3), 483-524. doi: 10.1016/j.psc.2009.06.002

Berk, L., Berk, M., Dodd, S., Kelly, C., Cvetkovski, S., \& Jorm, A. F. (2013). Evaluation of the acceptability and usefulness of an information website for caregivers of people with bipolar disorder. BMC Med, 11, 162. doi: 10.1186/1741-7015-11-162

Eysenbach, G. (2005). The law of attrition. J Med Internet Res, 7. doi: 10.2196/jmir.7.1.e11

Hart, L. M., Jorm, A. F., Paxton, S. J., \& Cvetkovski, S. (2012). Mental health first aid guidelines: an evaluation of impact following download from the world wide web. Early Interv Psychiatry, 6, 399-406.

Kessler, R. C., Angermeyer, M., Anthony, J. C., De Graaf, R., Demyttenaere, K., Gasquet, I., . . Ustun, T. B. (2007). Lifetime prevalence and age-of-onset distributions of mental disorders in the World Health Organization's World Mental Health Survey Initiative. World Psychiatry, 6(3), 168-176.

Lawrence, D., Johnson, S., Hafekost, J., Boterhoven De Haan, K., Sawyer, M., Ainley, J., \& Zubrick, S. R. (2015). The Mental Health of Children and Adolescents. Report on the second Australian Child and Adolescent Survey of Mental Health and Wellbeing. Canberra: Department of Health.

Melioli, T., Rispal, M., Hart, L. M., Chabrol, H., \& Rodgers, R. F. (2016). French mental health first aid guidelines for eating disorders: an exploration of user characteristics and usefulness among college students. Early Intervention in Psychiatry, n/a-n/a. doi: 10.1111/eip.12369

Oinas-Kukkonen, H., \& Harjumaa, M. (2009). Persuasive Systems Design: Key issues, process model, and system features. Communications of the Association for Information Systems, 24, 485-500.

Parenting Strategies Program. (2013). How to prevent depression and clinical anxiety in your teenager: Strategies for parents. Melbourne: beyondblue.

Powell, J., \& Clarke, A. (2006). Internet information-seeking in mental health: population survey. Br J Psychiatry, 189, 273-277.

Reavley, N. J., \& Jorm, A. F. (2010). The quality of mental disorder information websites: A review. Patient Educ Couns, 85(2), e16-25. doi: S0738-3991(10)00623-3 [pii]

10.1016/j.pec.2010.10.015

Rosenstock, I. (1974). Historical Origins of the Health Belief Model. Health Education Monographs, 2(4).

Schwartz, O., Dudgeon, P., Sheeber, L., Yap, M., Simmons, J., \& Allen, N. (2012). Parental behaviors during family interactions predict changes in depression and anxiety symptoms during adolescence. J Abnormal Child Psychol, 40(1), 59-71. doi: 10.1007/s10802-011-9542-2

Sim, W. H., Jones, A. E., Jorm, A. F., \& Yap, M. B. H. (2017). The impact and reach of webbased parenting guidelines to prevent childhood depression and anxiety: Findings from online user surveys. Mental Health \& Prevention, 7, 1-7. doi: https://doi.org/10.1016/j.mhp.2017.05.001

Thapar, A., Collishaw, S., Pine, D. S., \& Thapar, A. K. (2012). Depression in adolescence. Lancet, 379(9820), 1056-1067. doi: 10.1016/S0140-6736(11)60871-4

Yap, M. B. H., \& Jorm, A. F. (2012). Parents' beliefs about actions they can take to prevent depressive disorders in young people: Results from an Australian national survey. Epidemiology and Psychiatric Sciences, 21, 117-123. doi: $10.1017 /$ S2045796011000667 
Yap, M. B. H., \& Jorm, A. F. (2015). Parental factors associated with childhood anxiety, depression, and internalizing problems: A systematic review and meta-analysis. $J$ Affect Disord, 175C, 424-440. doi: 10.1016/j.jad.2015.01.050

Yap, M. B. H., Jorm, A. F., Bazley, R., Kelly, C. M., Ryan, S. M., \& Lubman, D. (2011). Web-based parenting program to prevent adolescent alcohol misuse: rationale and development. Australasian Psychiatry, 19(4), 339-344. doi: 10.3109/10398562.2011.603334

Yap, M. B. H., Lawrence, K. A., Rapee, R. M., Cardamone-Breen, M. C., Green, J. M., \& Jorm, A. F. (under review). Partners in Parenting: A multi-level web-based approach to support parents in prevention and early intervention for adolescent depression and anxiety.

Yap, M. B. H., Morgan, A. J., Cairns, K., Jorm, A. F., Hetrick, S. E., \& Merry, S. (2016). Parents in prevention: A meta-analysis of randomized controlled trials of parenting interventions to prevent internalizing problems in children from birth to age 18 . Clinical Psychology Review, 50, 138-158. doi: http://dx.doi.org/10.1016/j.cpr.2016.10.003

Yap, M. B. H., Pilkington, P. D., Ryan, S. M., \& Jorm, A. F. (2014). Parental factors associated with depression and anxiety in young people: A systematic review and meta-analysis. Journal of Affective Disorders, 156, 8-23.

Yap, M. B. H., Pilkington, P. D., Ryan, S. M., Kelly, C., \& Jorm, A. F. (2014). Parenting strategies for reducing the risk of adolescent depression and anxiety disorders: a Delphi consensus study. Journal of Affective Disorders, 156, 67-75. 


\section{Tables}

Table 1

Survey 1 Responses and Comparisons between Completers of Survey 1 only, and Completers of Both Surveys

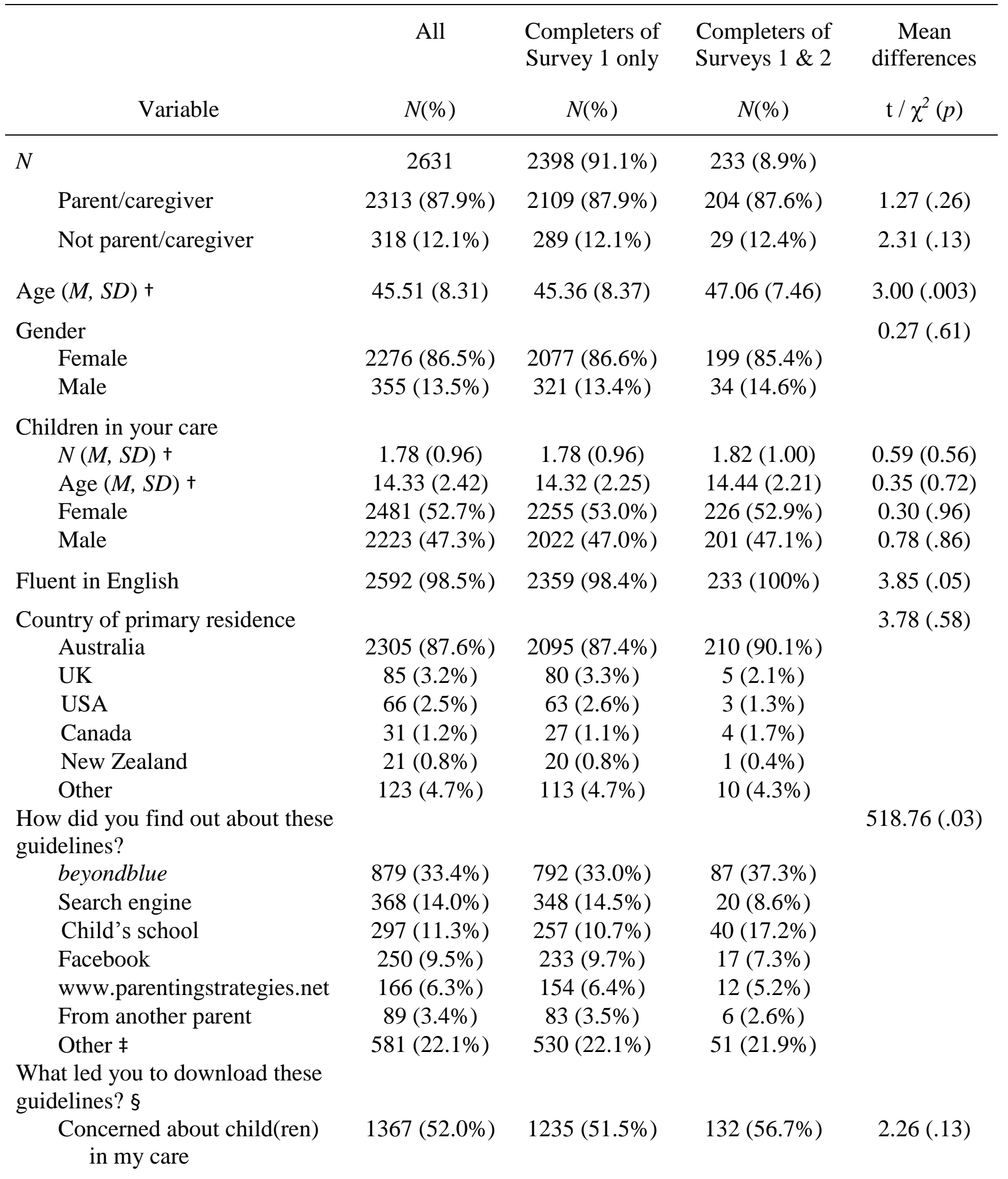




\begin{tabular}{|c|c|c|c|c|}
\hline $\begin{array}{l}\text { I would like to find out more } \\
\text { about how I can prevent } \\
\text { depression and anxiety } \\
\text { problems in child(ren) in } \\
\text { my care }\end{array}$ & $1311(49.8 \%)$ & $1190(49.6 \%)$ & $121(51.9 \%)$ & $0.45(.50)$ \\
\hline My job & $769(29.2 \%)$ & $699(29.1 \%)$ & $70(30.0 \%)$ & $0.08(.78)$ \\
\hline $\begin{array}{l}\text { Professional or student } \\
\text { interested in this topic }\end{array}$ & $574(21.8 \%)$ & $512(21.4 \%)$ & $62(26.6 \%)$ & $3.44(.06)$ \\
\hline $\begin{array}{l}\text { I know parents who might } \\
\text { find this useful }\end{array}$ & $384(14.6 \%)$ & $338(14.1 \%)$ & $46(19.7 \%)$ & $5.43(.02)$ \\
\hline $\begin{array}{l}\text { I'm just curious to see what's } \\
\text { in them }\end{array}$ & $212(8.1 \%)$ & $194(8.1 \%)$ & $18(7.7 \%)$ & $0.04(.85)$ \\
\hline Other $q$ & $89(3.4 \%)$ & $84(3.5 \%)$ & $5(2.1 \%)$ & $1.20(.27)$ \\
\hline $\begin{array}{l}\text { Issues with child in my } \\
\text { care }\end{array}$ & 34 & & & \\
\hline $\begin{array}{l}\text { My own issues / mental } \\
\text { health history }\end{array}$ & 17 & & & \\
\hline Professional interest & 11 & & & \\
\hline Desire to learn more & 10 & & & \\
\hline Other & 7 & & & \\
\hline
\end{tabular}

Note. $\mathrm{M}=$ Mean, $\mathrm{SD}=$ Standard Deviation.

t t-test used to calculate mean differences. All other comparisons used chi-squared tests.

‡ Notable 'Other' sources included: Work colleague/e-mail ( $n=87)$; Mental Elf $(n=41)$;

Newspaper article $(n=28)$; Red Informatica de Medicina Avanzada $(n=19)$; Mental Health First Aid ( $n=16)$.

$\S$ Multiple answers possible.

ๆ Qualitative analysis of 'Other' responses appears below this line. 
Table 2

Users' Perceived Usefulness of the guidelines

\begin{tabular}{|c|c|c|c|}
\hline \multirow[b]{3}{*}{ Variable } & \multicolumn{2}{|c|}{ Survey 2 version ${ }^{\dagger}$} & \multirow{3}{*}{$\begin{array}{c}\text { Chi-Square } \\
\chi^{2}(p)\end{array}$} \\
\hline & Parent/Caregiver & Other & \\
\hline & $N(\%)$ & $N(\%)$ & \\
\hline$N$ & 204 & 29 & \\
\hline $\begin{array}{l}\text { How much of the guidelines did you } \\
\text { read? }\end{array}$ & & & $1.97(.58)$ \\
\hline All of it & $130(63.7 \%)$ & $15(51.7 \%)$ & \\
\hline Most of it & $52(25.5 \%)$ & $10(34.5 \%)$ & \\
\hline Some of it & $19(9.3 \%)$ & $3(10.2 \%)$ & \\
\hline None of it & $3(1.5 \%)$ & $1(3.4 \%)$ & \\
\hline \multicolumn{4}{|l|}{$\begin{array}{l}\text { What did you do with the downloaded } \\
\text { guidelines? } \neq\end{array}$} \\
\hline Saved it or kept it & $181(88.7 \%)$ & $25(86.2 \%)$ & $0.16(.69)$ \\
\hline Forwarded or lent it to someone & $33(16.2 \%)$ & $10(34.5 \%)$ & $5.65(.02)$ \\
\hline Deleted it or threw it away & $7(3.4 \%)$ & $1(3.4 \%)$ & $0.00(.99)$ \\
\hline Don’t know & $12(5.9 \%)$ & $0(0 \%)$ & $1.79(.18)$ \\
\hline How much did you learn? & & & $5.13(.16)$ \\
\hline A great deal & $18(8.8 \%)$ & $2(6.9 \%)$ & \\
\hline A fair bit & $141(69.1 \%)$ & $15(51.7 \%)$ & \\
\hline Not very much & $26(12.7 \%)$ & $7(24.1 \%)$ & \\
\hline Almost nothing new & $19(9.3 \%)$ & $5(17.2 \%)$ & \\
\hline $\begin{array}{l}\text { Did they include things you wanted to } \\
\text { know? }\end{array}$ & & & $11.87(.01)$ \\
\hline Yes & $99(48.5 \%)$ & $22(75.9 \%)$ & \\
\hline Mostly & $81(39.7 \%)$ & $4(13.8 \%)$ & \\
\hline Partly & $20(9.8 \%)$ & $1(3.4 \%)$ & \\
\hline No & $4(2.0 \%)$ & $2(6.9 \%)$ & \\
\hline Did you find them useful? & & & $13.26(.01)$ \\
\hline Yes, very useful & $48(23.5 \%)$ & $14(48.3 \%)$ & \\
\hline Yes, useful & $133(65.2 \%)$ & $12(41.4 \%)$ & \\
\hline Not sure & $14(6.9 \%)$ & $0(0 \%)$ & \\
\hline No, I didn't use them & $7(3.4 \%)$ & $3(10.2 \%)$ & \\
\hline $\begin{array}{l}\text { No, I tried to use them but did not } \\
\text { find them helpful }\end{array}$ & $2(1.0 \%)$ & $0(0 \%)$ & \\
\hline $\begin{array}{l}\text { How likely are you to use them in the } \\
\text { future? }\end{array}$ & & & $4.85(.30)$ \\
\hline Very likely & $74(36.3 \%)$ & $15(51.7 \%)$ & \\
\hline Likely & $105(51.5 \%)$ & $12(41.4 \%)$ & \\
\hline Neither likely nor unlikely & $21(10.3 \%)$ & $1(3.4 \%)$ & \\
\hline Unlikely & $2(1.0 \%)$ & $1(3.4 \%)$ & \\
\hline
\end{tabular}



Very unlikely
$2(1.0 \%)$
$0(0 \%)$

+ Users received the Parent/Caregiver version if they indicated that they had at least one child under their care.

‡ Multiple answers possible 
Table 3

Why the Guidelines Were Perceived as Useful or Not Useful $(N=113)$

\begin{tabular}{lc}
\hline \multicolumn{1}{c}{ Categorisation ${ }^{\dagger}$} & $N(\%)$ \\
\hline Useful & \\
Good reference/discussion tool; clearly written & $42(37.2 \%)$ \\
Reminder/refresher of things already known & $16(14.2 \%)$ \\
Supportive; reassuring & $14(12.4 \%)$ \\
Good starting point & $10(8.8 \%)$ \\
Professional interest $\ddagger$ & $5(4.4 \%)$ \\
Specific issues with own child & $3(2.7 \%)$ \\
Not Useful & $18(15.9 \%)$ \\
Already knew most of the material & $5(4.4 \%)$ \\
Vague; needs to be more practical & $5(4.4 \%)$ \\
Looking for different information & $18(15.9 \%)$ \\
Answer not relevant to question $\S$ & \\
\hline
\end{tabular}

† Multiple categorisations possible per participant

‡ Psychologists, school counselors, teachers and others who work with adolescents

$\S$ Examples include parents wishing that they had the guidelines before their child became unwell; or noting the importance that parents are not made to feel "blamed" if their child becomes unwell. 
Table 4

Extent to Which Parent/Caregivers Had Tried to Improve in 13 Parenting Domains Since Reading the Guidelines $(N=204)$

\begin{tabular}{|c|c|c|c|c|c|c|c|}
\hline & $\begin{array}{l}\text { Not at } \\
\text { all }\end{array}$ & A little & Somewhat & A lot & $\begin{array}{l}\text { No need } \\
\text { to } \\
\text { change }\end{array}$ & N/A & $\begin{array}{c}A \\
\text { little } \\
\text { to } A \\
\text { lot }\end{array}$ \\
\hline Parenting domain & $N(\%)$ & $N(\%)$ & $N(\%)$ & $N(\%)$ & $N(\%)$ & $N(\%)$ & $\begin{array}{c}\text { (Total } \\
\%)\end{array}$ \\
\hline $\begin{array}{l}\text { Improving your } \\
\text { relationship with } \\
\text { your child }\end{array}$ & $\begin{array}{c}4 \\
(2.0 \%)\end{array}$ & $\begin{array}{c}33 \\
(16.2 \%)\end{array}$ & $\begin{array}{c}46 \\
(22.5 \%)\end{array}$ & $\begin{array}{c}64 \\
(31.4 \%)\end{array}$ & $\begin{array}{c}57 \\
(27.9 \%)\end{array}$ & - & 70.1 \\
\hline $\begin{array}{l}\text { Becoming more } \\
\text { involved in your } \\
\text { child's life }\end{array}$ & $\begin{array}{c}2 \\
(1.0 \%)\end{array}$ & $\begin{array}{c}24 \\
(11.8 \%)\end{array}$ & $\begin{array}{c}65 \\
(31.9 \%)\end{array}$ & $\begin{array}{c}37 \\
(18.1 \%)\end{array}$ & $\begin{array}{c}76 \\
(37.3 \%)\end{array}$ & - & 61.8 \\
\hline $\begin{array}{l}\text { Supporting your } \\
\text { child's increasing } \\
\text { autonomy }\end{array}$ & $\begin{array}{c}3 \\
(1.5 \%)\end{array}$ & $\begin{array}{c}38 \\
(18.6 \%)\end{array}$ & $\begin{array}{c}54 \\
(26.5 \%)\end{array}$ & $\begin{array}{c}56 \\
(27.5 \%)\end{array}$ & $\begin{array}{c}53 \\
(26.0 \%)\end{array}$ & - & 72.6 \\
\hline $\begin{array}{l}\text { Establishing } \\
\text { family rules and } \\
\text { consequences }\end{array}$ & $\begin{array}{c}11 \\
(5.4 \%)\end{array}$ & $\begin{array}{c}42 \\
(20.6 \%)\end{array}$ & $\begin{array}{c}72 \\
(35.3 \%)\end{array}$ & $\begin{array}{c}30 \\
(14.7 \%)\end{array}$ & $\begin{array}{c}49 \\
(24.0 \%)\end{array}$ & - & 70.6 \\
\hline $\begin{array}{l}\text { Minimising } \\
\text { conflict with your } \\
\text { child }\end{array}$ & $\begin{array}{c}5 \\
(2.4 \%)\end{array}$ & $\begin{array}{c}31 \\
(15.2 \%)\end{array}$ & $\begin{array}{c}56 \\
(27.5 \%)\end{array}$ & $\begin{array}{c}70 \\
(34.3 \%)\end{array}$ & $\begin{array}{c}42 \\
(20.6 \%)\end{array}$ & - & 77.0 \\
\hline $\begin{array}{l}\text { Avoiding } \\
\text { criticising your } \\
\text { child }\end{array}$ & $\begin{array}{l}3 \\
(1.5 \%)\end{array}$ & $\begin{array}{c}33 \\
(16.2 \%)\end{array}$ & $\begin{array}{c}44 \\
(21.6 \%)\end{array}$ & $\begin{array}{c}70 \\
(34.3 \%)\end{array}$ & $\begin{array}{c}54 \\
(26.5 \%)\end{array}$ & - & 72.1 \\
\hline $\begin{array}{l}\text { Minimising } \\
\text { conflict with your } \\
\text { partner }\end{array}$ & $\begin{array}{c}10 \\
(4.9 \%)\end{array}$ & $\begin{array}{c}27 \\
(13.2 \%)\end{array}$ & $\begin{array}{c}49 \\
(24.0 \%)\end{array}$ & $\begin{array}{c}20 \\
(9.8 \%)\end{array}$ & $\begin{array}{c}53 \\
(26.0 \%)\end{array}$ & $\begin{array}{c}45 \\
(22.1 \%)\end{array}$ & $47.0^{\mathrm{a}}$ \\
\hline $\begin{array}{l}\text { Encouraging } \\
\text { supportive } \\
\text { relationships }\end{array}$ & $\begin{array}{c}7 \\
(3.4 \%)\end{array}$ & $\begin{array}{c}17 \\
(8.3 \%)\end{array}$ & $\begin{array}{c}65 \\
(31.9 \%)\end{array}$ & $\begin{array}{c}72 \\
(35.3 \%)\end{array}$ & $\begin{array}{c}43 \\
(21.1 \%)\end{array}$ & - & 75.5 \\
\hline $\begin{array}{l}\text { Encouraging good } \\
\text { health habits }\end{array}$ & $\begin{array}{c}6 \\
(2.9 \%)\end{array}$ & $\begin{array}{c}22 \\
(10.8 \%)\end{array}$ & $\begin{array}{c}54 \\
(26.5 \%)\end{array}$ & $\begin{array}{c}75 \\
(36.8 \%)\end{array}$ & $\begin{array}{c}47 \\
(23.0 \%)\end{array}$ & - & 74.1 \\
\hline $\begin{array}{l}\text { Helping your } \\
\text { child to deal with } \\
\text { problems }\end{array}$ & $\begin{array}{c}7 \\
(3.4 \%)\end{array}$ & $\begin{array}{c}37 \\
(18.1 \%)\end{array}$ & $\begin{array}{c}66 \\
(32.4 \%)\end{array}$ & $\begin{array}{c}61 \\
(29.9 \%)\end{array}$ & $\begin{array}{c}33 \\
(16.2 \%)\end{array}$ & - & 82.2 \\
\hline $\begin{array}{l}\text { Helping your } \\
\text { child to deal with } \\
\text { anxiety }\end{array}$ & $\begin{array}{c}13 \\
(6.4 \%)\end{array}$ & $\begin{array}{c}42 \\
(20.6 \%)\end{array}$ & $\begin{array}{c}62 \\
(30.4 \%)\end{array}$ & $\begin{array}{c}57 \\
(27.9 \%)\end{array}$ & $\begin{array}{c}30 \\
(14.7 \%)\end{array}$ & - & 78.9 \\
\hline $\begin{array}{l}\text { Encouraging } \\
\text { professional help }\end{array}$ & $\begin{array}{c}9 \\
(4.4 \%)\end{array}$ & $\begin{array}{c}22 \\
(10.8 \%)\end{array}$ & $\begin{array}{c}41 \\
(20.1 \%)\end{array}$ & $\begin{array}{c}66 \\
(32.4 \%)\end{array}$ & $\begin{array}{c}50 \\
(24.5 \%)\end{array}$ & $\begin{array}{c}16 \\
(7.8 \%)\end{array}$ & $63.3^{\mathrm{a}}$ \\
\hline
\end{tabular}


seeking when

needed

Not blaming

yourself for

17

$(8.3 \%)-(\mathbf{2 4 . 0 \%})$

46

35

45

12

$63.7^{\mathrm{a}}$

problems your

child is facing

Mean $N(\%)$

$7 \quad 32$

55

$\begin{array}{lllll}(3.7 \%) & (15.7 \%) & \mathbf{( 2 7 . 1 \%} & (26.9 \%) & (23.8 \%)\end{array}$

55

49

Note. N/A = Not applicable. Bold type denotes the modal response for each parenting domain.

† These percentages were computed after excluding participants who indicated that this domain was not applicable (N/A) to them. 
Table 5

Responses to the question "Would you (Parent/Caregiver version)/Do you think parents or caregivers would (Other version) find it useful if these guidelines were used as the basis for developing the following:"

\begin{tabular}{|c|c|c|c|c|c|c|c|c|}
\hline \multirow[b]{2}{*}{ Additional component } & \multicolumn{4}{|c|}{ Parents / caregivers $(N=204)$} & \multicolumn{4}{|c|}{ Other completers $(N=29)$} \\
\hline & $\begin{array}{r}\text { Yes, very } \\
\text { useful }\end{array}$ & Yes, useful & $\begin{array}{l}\text { Not sure, } \\
\text { maybe }\end{array}$ & No & $\begin{array}{l}\text { Yes, very } \\
\text { useful }\end{array}$ & Yes, useful & $\begin{array}{l}\text { Not sure, } \\
\text { maybe }\end{array}$ & No \\
\hline Personalised feedback report ${ }^{\dagger}$ & $59(28.9 \%)$ & $89(43.6 \%)$ & $48(23.5 \%)$ & $8(3.9 \%)$ & $13(44.8 \%)$ & $12(41.4 \%)$ & $3(10.3 \%)$ & $1(3.4 \%)$ \\
\hline $\begin{array}{l}\text { An interactive web-based } \\
\text { parenting program } \ddagger\end{array}$ & $89(43.6 \%)$ & $88(43.1 \%)$ & $24(11.8 \%)$ & $3(1.5 \%)$ & $16(55.2 \%)$ & $11(37.9 \%)$ & $2(6.9 \%)$ & $0(0 \%)$ \\
\hline $\begin{array}{l}\text { A seminar or workshop for } \\
\text { parents, supplemented by a } \\
\text { web-based program§ }\end{array}$ & $67(32.8 \%)$ & $70(34.3 \%)$ & $52(25.5 \%)$ & $\begin{array}{c}15 \\
(7.4 \%)\end{array}$ & $12(41.4 \%)$ & $11(37.9 \%)$ & $6(20.7 \%)$ & $0(0 \%)$ \\
\hline
\end{tabular}

†A personalised feedback report that outlines areas of strength and areas requiring improvement in the parent's current parenting practices, based on their responses to a self-assessment online survey;

‡ A program which supports parents in applying the strategies presented in the guidelines. This may include more specific information, practical tips and suggestions for troubleshooting, activities parents can do with their child, goal-setting activities etc. Parents will be able to progress through the program at their own pace, and complete it in a place and time that suits them;

§ A seminar or workshop that highlights the key topics covered in the guidelines, which is supplemented by a web-based program 
Table 6

Users' Suggestions for Improving the guidelines $(N=71)$

\begin{tabular}{lll}
\hline \multicolumn{1}{c}{ Categorisation } & $N(\%)$ & \multicolumn{1}{c}{ Example response } \\
\hline $\begin{array}{l}\text { Include barriers to implementing; } \\
\text { dealing with uncooperative teens }\end{array}$ & $14(19.7 \%)$ & $\begin{array}{l}\text { More content on what to do if } \\
\text { the child resists attempts to } \\
\text { implement the strategies in the } \\
\text { guidelines. }\end{array}$ \\
& Theduce in other formats/technologies $115.5 \%)$ & $\begin{array}{l}\text { There is quite a lot to read and } \\
\text { parents need to be motivated to } \\
\text { get through all the sheets. Is } \\
\text { there a way to utilise main bullet } \\
\text { points? Have you thought of pod } \\
\text { casts so parents could listen to } \\
\text { the information while driving or } \\
\text { doing some other activity. Is } \\
\text { there an App or is there a } \\
\text { Smartphone version? }\end{array}$ \\
&
\end{tabular}
Checklists/brief versions for handing $\quad 7$ (9.9\%) Perhaps a summary for out
professionals to give to parents.
Shorter and bullet pointed.

Make the guidelines more user friendly

$6(8.5 \%) \quad$ I thought the language could be more user friendly. Some of it seemed to be a bit "academic". More 'real life' scenarios could be used.

Include examples of implementing $4(5.6 \%) \quad$ Perhaps something on how to strategies explain anxiety and depression to other children in the family. Strategies for reducing conflict. 
Other

No suggestion; answer not relevant to question
$5(7.0 \%) \quad$ Perhaps a few images of people sporting tattoos, less

conservative hair cuts, an

Indigenous family etc. 
Figure Legends

Figure 1. Flow of participants

Visitors to website who downloaded the Guidelines ( $N=26977$ )

Users who completed

Survey 1 ( $N=2631)$

Users who consented to receive Survey 2

$(\mathrm{N}=1559)$

Users invited to complete

Survey 2 (N=1490, 57\%; 1336

Parent, 154 Other)
Users excluded $(n=69)$

Reasons:

-Did not consider themselves fluent in English ( $n=20)$

-Aged below 16 years $(n=1)$

-Technical error; not sent an invitation to Survey $2(n=48)$

\footnotetext{
Users who completed Survey 2 (N=233, 9\%; 204 Parent, 29 Other)
} 